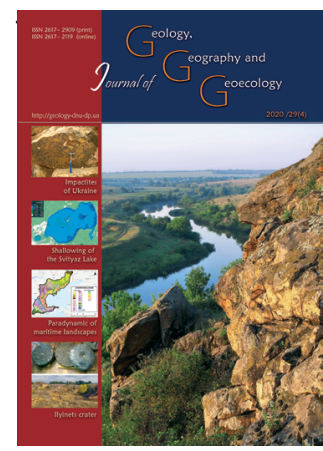

\title{
Areal communities' centres of Poltava Region as social-economic growth poles
}

Serhii M. Shevchuk

\section{Poltava V. G. Korolenko National Pedagogical University, Poltava, Ukraine, S_Sevchuk@online.ua}

Received: 31.03 .2020

Received in revised form: 06.07.2020

Accepted: 08.09.2020

Abstract. The article embraces the thorough analysis of the social-economic space of Poltava Region via administrative-areal reform as well as united areal communities' formation. Given research has its base in the methodology of spatial analysis of areal systems with different levels of their organization. As a result, the very essence of social-economic growth poles' forming process was revealed in succession. The fact this growth poles' formation on depressive territories tends to be the ultimate way to improve their social and economic status has been logically ascertained. The typification of Poltava Region united areal communities' centres as social-economic growth poles was held according to such criteria as their formation and impact extension over the surrounding territory. Actually, the forming peculiarities and the further development of growth poles on the regional level have an urgent necessity under active administrative-areal reform. Therefore, the prerequisites and the forming factors of Poltava Region growth poles were clearly defined. As a result, all the groups' types of regional social-economic centres, which are already formed social-economic development poles (Poltava, Kremenchuh), development poles under formation (Horishni Plavni, Myrhorod, Lubny, and Hadiach), centres with some prerequisites to transform into growth poles (Karlivka, Pyriatyn, Lokhvytsa, Zinkiv, Hlobyne, and Kobeliaky), and centres with insufficient capacity to transform into growth poles (Velyka Bahachka, Kozelshchyna, Mashivka, Novi Sanzhary, Opishnia, Reshetylivka, Semenivka, Chornukhy, and Shyshaky), have been classified correctly. Those centres that have low formation level, being unable to transform into growth pole (Bilotserkivka, Butenky, Velyki Sorochyntsi, Drabynivka, Zavorsklo, Zasullia, Klepachi, Kolomatske, Krasna Luka, Lanna, Mala Pereshchepyna, Machukhy, Mykhailivka, Nedoharky, Nekhvoroshcha, Novoavramivka, Novoznamianka, Obolon, Omelnyk, Petrivka-Romenska, Pishchane, Pokrovska Bahachka, Pryshyb, Rokyta, Rudenkivka, Sencha, Serhiivka, Skorokhodove, Tereshky, Shcherbani), consolidate into the specific pattern. The results of the research aim to provide the primary, administrative, and social-economic UAC centers' functions. As a matter of fact, the fundamental prerequisite of the Poltava Region' area sustainable social-economic development can be efficiently contributed by already formed poles. They are, in fact, able to maintain the conservation of regional ecosystems, the areas' innovative development achievements, the overcome of poverty, the preservation of national values and traditions, etc. Only the transformation of the described centers or acquiring them the nuclei traits of social-economic development poles should ensure the balanced areal development of the region.

Key words: Poltava Region, administrative-areal order, UAC (united areal community), centre, social-economic development

\section{Центри територіальних громад Полтавської області як полюси соціально-економічного зростання}

\section{С. М. Шевчук}

Полтавський національний педагогічний університет імені В. Г. Короленка, Полтава, Украӥна, S_Sevchuk@online.ua

Анотація. Стаття включає комплексний аналіз соціально-економічного простору Полтавської області крізь призму адміністративно-територіальної реформи та формування об'єднаних територіальних громад. Робота базується на методології просторового аналізу територіальних систем різного рівня організації. Методика дослідження передбачала послідовне виконання наступних операцій: визначення ролі і місця центрів ОТГ в економіці, територіальній структурі господарства $\mathrm{i}$ розселенні населення; дослідження чинників, які визначають процеси розвитку центрів ОТГ; аналіз взаємовпливів розвитку господарства, його спеціалізації і центрів ОТГ; визначення сучасного стану і тенденції розвитку центрів ОТГ сільських районів; установлення ролі центрів ОТГ у формуванні господарських систем; обгрунтування моделі класифікації центрів ОТГ як полюсів зростання; проектування напрямів розвитку полюсів зростання на базі центрів ОТГ. Розкрито сутність процесу формування полюсів соціально-економічного зростання. Установлено, що формування полюсів зростання на депресивних територіях є єдиним шляхом покращення їх соціально-економічного стану. Здійснено типізацію центрів об'єднаних територіальних громад Полтавської області як полюсів соціально-економічного зростання за критеріями сформованості та 
масштабами впливу на навколишню територію. Підтверджено, що на тлі проведення адміністративно-територіальної реформи особливості формування й подальшого розвитку полюсів зростання на регіональному ріні мають виключну актуальність. Визначено передумови і умови формування полюсів зростання у Полтавській області. Результатом дослідження $є$ виділення типів груп регіональних соціально-економічних центрів: сформовані полюси соціально-економічного розвитку; полюси розвитку, що формуються; центри, що мають передумови для трансформації у полюси зростання; центри, 3 недостатніми можливостями для трансформації у полюси зростання. В окрему групу виділено центри з найнижчим рівнем сформованості, що фактично не мають можливості для трансформації у полюси зростання. Результати дослідження спрямовані на забезпечення не лише ключової адміністративної, а й соціально-економічної функції центрів територіальних громад. Доведено, що базовою передумовою сталого соціально-економічного розвитку території Полтавської області є сформовані полюси, що здатні забезпечити збереження регіональних екосистем, досягнення інноваційного розвитку територій, подолання бідності, збереження національних цінностей і традицій тощо. Трансформування виділених центрів чи набуття ними головних ознак полюсів соціально-економічного розвитку зможуть забезпечити збалансований територіальний розвиток області.

Ключові слова: Полтавська область, адміністративно-територіальний устрій, об'єднана територіальна громада, иентри, соиіально-економічний розвиток

Introduction. Up-to-date tendencies of Poltava Region social and economic space uplift as well as the decline of branches, has been dominant in economic activity specialization, the territorial disproportion on the development of towns and rural areas, the depopulation likewise the decrease of population's life conditions and quality are those crucial traits, which nowadays form the background of national regional policy. The administrative-areal order reform bares the status of the key one at the areal development. It has been set up in conjunction with so-called decentralization reform, resulting in united areal communities' (UAC - hereafter) formation. Nowadays the mentioned above process has its active prolongation in Poltava Region; it provides the further association of local councils for rational usage of local budget and successive increase of the population's life quality likewise the sustainable growth of the area.

In up-to-date terms, the necessity of a new country's regionalisation stems from Ukraine's strategic priority for EU integration, preceding by the administrative-areal order formation, as per NUTS (Nomenclature of Territorial Units for Statistics) requirements. The conceptual framework of the given article addresses Ukraine's official papers, including the Presidential Decree "On the Concept of a Regional Public Policy" (2001), the Laws of Ukraine "On the Principles of a Regional Public Policy" (2015) and "On a Voluntary Unification of Areal Communities" (version of 2019). It also takes into account the Cabinet of Ministers Resolutions "On the Amendment of Methods of Competent Areal Communities' Formation" (2020) and the Methodical Recommendations on the criteria of sub-regional (district) administrative-areal units' formation (2019). The elaboration of principal theses of areal development, based on the theory of growth poles, was founded on acquisitions of François Perroux, Jose Ramon Lasuen, Immanuel Wallerstein, George Friedman, and Stig Torsten Erik Hägerstrand.
The core of this theory defines the role of dominant branches of economy in a certain locality, referring to their potential to cause economic growth in the whole influence area. Diverse aspects of the areal development occurred in the research focus of many Ukrainian economic geographers, such as Y. Pitiurenko, I. Horlenko, S. Ishchuk, O. Shablii, A. Dotsenko, A. Stepanenko, O. Topchiyev, Y. Oliinyk, M. Baranovskyy, V. Yavorska, etc. Significant scientific studies have been held in the field of public administration, particularly in substantiation of the principles of areal development management, areal development forecasting (K. Mezentsev, 2005), geoplanning (Malchykova, 2014), geospatial research and spatial planning practice (L. Rudenko, S. Lisovskyi, Y. Maruniak, 2016). The areal development theories' key principles, having been successfully adapted to market conditions, represent the results on increasing competitiveness, production specialization and balanced areal development as well as ascertain market infrastructure creation, areal industries organization and reveal the growth poles in the context of spatial inequality and polarization. The amount of these issues was logically displayed in disquisitions by S. Zapotoczkij (2012), K. Mezentsev, N. Mezentseva, H. Pidhrushnyy (2014), I. Pilipenko (2015), O. Topchiyev, D. Malchykova, V. Yavorska (2015), etc. The problem also got its deep consideration during the seminar, held at the Institute of Geography of The National Academy of Sciences of Ukraine (2013). It is true fact, that the theory of economic space gets a wide prevalence in Ukrainian social geography; peculiar attention is being paid to the problem of economic space, focused upon the district-forming nuclei or specific areas. To solve the crucial problems of the Poltava Region areal development, to decrease disproportions in social and economic growth of its area or certain localities, to optimize the industry branch structure likewise the population resettlement the thorough scientific search has to be directed into the 
exposure, incitement and support of the new social and economic growth poles. The majority of Poltava Region rural areas became depressive territories during the Independence period; they represent ineffective branch structure of the economy with the leading role and share of raw-oriented industries, lack of agricultural competitiveness, cattle-breeding in particular, unemployment, increase of migration, and depopulation of inhabitants. General geodemographic situation in Poltava Region reveals the ultimate risks for the future development of this area, mainly due to the gradual decrease of natural population growth, unbalanced sexual and aged structure of the population, which is a deterrent in the reproduction mode of the latter, causing the fast decline of inhabitants in total. The administrative-areal order of Poltava Region (districts, various by area, configuration, and population, long distances to administrative centres, etc.) determines different efficiency of these centres in their functions' execution. The mentioned above problems are among essential obstacles in the further effective development of the local area; they actually minimize state reforms' implementation efficiency in stimulating areas development and do not contribute the effective fulfilment of Poltava Region social-economic potential.

The effective system of growth poles should play an exclusive role in the problems' solution. As development indicators, these centres have to become drivers of long-awaited changes of Poltava Region's social-economic space according to the district-forming effect and to spread the development impulses over surrounding areas. Growth poles' forming process also should lead to the improvement of the region's areal structure, stimulating dominant branches of economy. Thus, the necessity to make a perspective social-economic development poles' model got its particular relevance in terms of Poltava Region development strategic planning. Potentially it will embrace scientifically sound analysis of polarization and depressiveness of the social-economic space of the region likewise will provide typification of the UAC centres as socialeconomic development poles. It also will ascertain and predict their role in the process of Poltava Region areal society structure improvement. The utmost achievement of the given above aspects depends on thorough analysis and modelling of areal processes of Poltava Region economic complex development, and all the branches of its specialization, especially considering those connected via production ties with agriculture. Similarly, it depends on the scrupulous analysis and modelling of processes of transport infrastructure and social sphere development, population employment ensuring, and areal optimizing of inhabitants' life quality indicators set. Actually, fundamental implementation of this approach into the areal prognostication practice and social-economic development planning can provide UAC centres with the status of growth poles not only by towns but also by localities in some rural areas as basic components of Poltava Region social-economic development. The persistent improvement of infrastructure, stimulation of the manufacturing industry, agriculture and social sphere branches' development are the very incitements to transform these centres into important cells of social-economic development of surrounding territories and the region in total.

The aim of the given research is to provide the comprehensive analysis of the formation level of Poltava Region UAC centres as social-economic growth poles and to justify suggestions of its further development. During the acquisition the fact the growth poles' forming, on the one hand, reveals to be the objective process of social-economic development and simultaneously the means of achieving territorial disproportions in the population life level and quality was put into consideration. On the other hand, the growth poles' forming could also be a result of purposeful implementation of state regional policy or investment projects. The essence of the research lies in finding out the processes of forming (re-forming) and functioning of areal structures at the grassroots level in the line of regional policy implementation to improve the level and quality of population's life.

The research methodology of UAC centres as socialeconomic growth poles has its basis on fundamental methodological principles of the social geography. Given study is grounded on doctrine of complexand system-formation, manifested in areal selforganisation of all the spheres of human activity, in emergence and expansion of social-economic ties and relations, in the natural environment transformation, and areal communities' consolidation. Areal selforganisation of the society has traits of differentiation and discreteness, which become apparent in a form of administrative-areal order and system of regions of various taxonomic rank. Regional units of any hierarchical level are areal systems, actually realized in social-geographic space and historical timeline. During the process of society spatial self-organisation improvement the grassroots level areas' centres' are formed, making the possibility to combine governance and market self-regulation.

The detection of functions and role of UAC centres was held on the base of theoretical theses of the 
"centre - periphery" modelled by George Friedman. Reducing functioning efficiency of the economic complex, the decline of its competitiveness as well as imperfect regional development policy and demogeographic situation exacerbation cause the loss of traditional development resource base of the majority of Poltava Region areas. In fact, methodological basis of UAC centres research has its roots in scientific works by Johann Heinrich von Thünen, who conducted the model of spatial development of economic systems around centres of production consumption.

Persuasive usage of these approaches simultaneously to analysis of UAC centres comprehensive state of Poltava Region, located in rural areas, logically ascertained the evidence of sustainable interconnection trends between UAC centres, being mainly small towns or urban settlements, and social-economic state of surrounding territory. At the same time, in terms of market transformations, connected primarily to the impact of information technologies and scientifictechnological progress on branch structure of economy, this process significantly complicated and gained the new meaning. Therefore, the pre-dominant prerequisites of growth poles' effective formation are the objective analysis of branches of UAC economy specialization, identification of their raw materials sources, forecasting and modelling conditions, favourable for mutual UAC centres and surrounding territory development. Those poles' economic activation can be powerfully provided by innovative development of the economy, competitiveness increase of production, and involvement of specialized industries into regional, interregional, and globe networks.

The research methodology of identifying socialeconomic growth poles' level of forming on the base of UAC centres covers such essential aspects as:

1) place and role of UAC centres in a regional system of population resettlement, branch and areal structure of economy;

2) impact of social-geographical processes (natural, ecological, historical-geographical, demographical, ethnical, religious, political, economic, etc.) on the development of UAC centres;

3) mutual influence of the development of economy, its specialization and UAC centres;

4) comprehensive state and development trends of UAC centres (geodemographic characteristics, population employment structure, migration processes, economy specialization, development state of social sphere);

5) UAC centres competitive advantages in the process of regional and interregional economic systems' networks forming;
6) classification of UAC centres as social-economic growth poles with a mandatory analysis of their inertial impact on UAC area;

7) forecasting, modelling, and programming of development of UAC centres as growth poles in terms of depressive territories overcoming.

Concurrent to justifying the possibilities of UAC centres social-economic development likewise forming the growth poles on their base the previous indepth analysis revealed the specificity of areas development alongside with centres' functions in regional resettlement systems forming and development, and changes' trends in geodemographic sphere. The core issue of the represented research lies in the defining the role and place of the UAC and its centre in the areal structure of production and population resettlement, determining their natural-resource, geodemographic, transport-geographical, and economic-geographical position. The final stage of the research embraces the entire analysis of the inner factors of the further development of UAC centres as well as their potential and possibilities to establish economic and social connections with neighbouring areas, to widen the branch structure and to diversify the economy, to elaborate tour-recreational activity.

Thus, the base of the Poltava Region UAC centres, mainly its depressive rural areas, research methodology comprises its intensive study as growth poles. Among the most significant mandatory preconditions, one can name the objective classification of UAC centres after their abilities and substantiation of the most appropriate development scenario variants via UAC area social-economic increase. To do so one should enlist various criteria of centres' classification, especially rates of formation of innovative enterprises of multiple economy specialization branches, terms of their efficiency and production quality increase, integration of higher level of organization into economic systems, achievement of social effect, job positions creation, etc. As a result, the research efficiency and effectiveness of Poltava Region UAC centres as social-economic growth poles is exclusively determined by trends and rates of their impact on the complex development of the community area in general.

Results and discussion. Social-economic growth poles are represented by areal complexes, affiliated by diverse industrial and infrastructural interrelations. Due to their specific state and predicted rates of development, possibilities of usage of areal labour division advantages as well as development rates of specialized branches of economy, growth poles can be divided on real-existing and potentially-predictable ones. These poles as spatial increase nuclei objectively 
exemplify higher development rates compared to the area of attraction. Inertial impacts of the formed poles, however, regularly lead to social and economic lifting of the UAC in general. These poles have to represent certain kinds of economic activity, material (historicalcultural, sacred objects) and non-material (area brand, active-participating population) assets, able to produce the increase effects. Their stimulating impact on the social-economic growth of surrounding territories marks the crucial trait of these poles' development.

Modern Poltava Region is an administrative-areal unit of Ukraine the centre of which is Poltava city; it incorporates 25 districts, 15 cities ( 6 of them are of regional importance, they are Poltava, Kremenchuh, Horishni Plavni, Lubny, Myrhorod, and Hadiach), 21 towns, and 1805 villages. City, town and village councils unite certain number of localities around, they possess common infrastructure and support economic and social interrelations. Each district embodies an average amount of $69-70$ villages, consolidated into $18-19$ village councils. The average districts' area of Poltava Region makes $1150 \mathrm{~km}^{2}$. Regional decentralization reform manifested the reformation of 174 local councils by creating (up to January 01, 2019) 45 UACs (6 city UACs, 10 town UACs, and 29 village UACs, in particular). They joint about $34.6 \%$ of local councils of the region, it corresponds to $30.2 \%$ of the region area, and unites $22.5 \%$ of the region population. Up from the beginning of 2019 Poltava Region experienced creation of 8 more communities (Horishni Plavni, Novoselivka, Novoorzhytske, Hoholeve, Romodan, Petrivka, Zinkiv, and Velyki Budyshcha). As of October, 01, 2019 Poltava Region reveals 53 UACs, having consolidated 193 local councils (which makes $38.4 \%$ of their total amount), general UACs area makes $9.700 \mathrm{~m}^{2}$ (it is $33.9 \%$ of the region area), the UACs population counts 0.411 million people $(29.3 \%$ of the region inhabitants). It is worthy to mention, that one of the vivid drawbacks in the UACs forming process is the creation of 35 communities, incorporating less than 5000 people.

During 2018, Sencha UAC of Lokhvytsa district ascertained the maximum level (23733.7 UAH per capita) of tax revenues, while Zavorsklo UAC of Poltava district has shown the minimum level (2315.9 UAH per capita) of the earnings. As for September, 01, 2019, the general volume of all the 45 UACs' budgets formed the sum of 2100.8 million $\mathrm{UAH}$, that is $21.0 \%$ (or 364.5 million UAH) more compared to the corresponding period of 2018. Own receipts (without transfers) of UACs has risen by $26.6 \%$ (or 298.6 million UAH); it was 1419.6 million
UAH as for September, 01, 2019, and 1121.0 million UAH as for September, 01, 2018. The full monitoring of UACs' income dynamics in 2016 - 2018 unequivocally certifies their increase. In 2016 at 12 UACs such income (including transfers) has grown by 4 times compared to 2015; in 2017 at 18 UACs the income has increased by 1.6 times compared to 2016, and in 2018 at 39 UACs the income grew by 1.6 times compared to 2017. Actually, the income of certain communities rose by from 2 to 8 times. In fact, in 2018 Semenivka UAC had the income (including transfers) increased by $74.7 \%$ compared to 2017 , Pyriatyn UAC had the sum grown by $49.5 \%$; Machukhy UAC, Drabynivka UAC, Rokyta UAC, Velyka Bahachka UAC, and Nekhvoroshcha UAC disposed the amount risen by from 4 to 5 times. The rest of the newly conglomerated communities revealed the revenues increase by from 2 to 3 times during the very first year of national budget decentralization.

Thus, in terms of financial capacity Poltava Region UACs occupy the leading position in all-Ukrainian terrain for the first half of the year 2019. Taking into account UACs with total amount of inhabitants forged from 10000 to 15000 people one should range them as follows: Hlobyne UAC - the $5^{\text {th }}$ position, Shyshaky UAC - the $7^{\text {th }}$ position, Shcherbani UAC - the $8^{\text {th }}$ position, Lokhvytsa UAC - the $11^{\text {th }}$ position, Hrebinka UAC - the $14^{\text {th }}$ position. The group of UACs cooperating from 5000 to 10000 people represent their rank as those: Opishnia UAC - the $14^{\text {th }}$ position, Mykhailivka UAC - the $16^{\text {th }}$ position, and Mashivka UAC - the $20^{\text {th }}$ position. Having consolidated less than 5000 of persons, UACs of Poltava Region make their rank as follows: Drabynivka UAC - the $3^{\text {rd }}$ position, Sencha UAC - the $5^{\text {th }}$ position, Krasna Luka UAC the $8^{\text {th }}$ position, Kolomatske UAC - the $13^{\text {th }}$ position, Lanna UAC - the $15^{\text {th }}$ position. Hadiach UAC held the $18^{\text {th }}$ position among the cities of regional importance (Shevchuk, 2019).

Nowadays in terms of the state management crisis as well as decentralization process the Region urgently needs qualitative and quantitative administrativeareal order reformation, realized in UACs creation. Comprehensive Poltava Region AAO order reforming tends to be an important direction in state governing system improvement at the grassroots level, in upgrading the population living standards, rational usage of natural resources, and sustainable development of the region. Therefore, the AAO order reformation is rather complicated and long-termed process, the successful result of which depends on the thorough study and evaluation of diverse factors and indicators, necessary to UACs or new districts and regions bound- 
Table 1. Parameters of Poltava Region UACs as of January, 01, 2019.

\begin{tabular}{|c|c|c|c|c|}
\hline № & District & UAC & $\begin{array}{l}\text { Population amount } \\
\text { (according to State Statistics Service } \\
\text { of Ukraine as for January 01, 2019) }\end{array}$ & $\begin{array}{l}\text { Community area, } \mathrm{km}^{2} \\
\text { (according to State Geoca- } \\
\text { dastre) }\end{array}$ \\
\hline 1 & \multirow[t]{3}{*}{ Velyka Bahachka } & Bilotserkivka & 3601 & 200.693 \\
\hline 2 & & Velyka Bahachka & 10175 & 332.633 \\
\hline 3 & & Rokyta & 1901 & 111.839 \\
\hline 4 & \multirow[t]{4}{*}{ Hadiach } & Hadiach & 24622 & 72.484 \\
\hline 5 & & Krasna Luka & 3739 & 215.244 \\
\hline 6 & & Petrivka-Romenska & 4368 & 210.065 \\
\hline 7 & & Serhiivka & 2827 & 167.618 \\
\hline 8 & Hlobyne & Hlobyne & 14503 & 405.196 \\
\hline 9 & Hrebinka & Hrebinka & 12388 & 78.348 \\
\hline 10 & Zinkiv & Opishnia & 6238 & 131.438 \\
\hline 11 & Karlivka & Lanna & 3786 & 96.765 \\
\hline 12 & Kobeliaky & Butenky & 3649 & 143.855 \\
\hline 13 & \multirow[t]{2}{*}{ Kozelshchyna } & Kozelshchyna & 10404 & 491.541 \\
\hline 14 & & Nova Haleshchyna & 3508 & 59.225 \\
\hline 15 & \multirow[t]{5}{*}{ Kremenchuh } & Nedoharky & 3520 & 84.774 \\
\hline 16 & & Novoznamianka & 4464 & 82.690 \\
\hline 17 & & Omelnyk & 5019 & 224.821 \\
\hline 18 & & Pishchane & 6453 & 78.028 \\
\hline 19 & & Pryshyb & 1957 & 91.910 \\
\hline 20 & \multirow[t]{2}{*}{ Lokhvytsa } & Lokhvytsa & 12410 & 81.672 \\
\hline 21 & & Sencha & 2954 & 125.068 \\
\hline 22 & Lubny & Zasullia & 16377 & 604.300 \\
\hline 23 & \multirow[t]{2}{*}{ Mashivka } & Mashivka & 7490 & 136.457 \\
\hline 24 & & Mykhailivka & 6009 & 444.333 \\
\hline 25 & Myrhorod & Velyki Sorochyntsi & 3603 & 130.756 \\
\hline 26 & \multirow[t]{5}{*}{ Novi Sanzhary } & Drabynivka & 4265 & 245.778 \\
\hline 27 & & Nekhvoroshcha & 5164 & 287.462 \\
\hline 28 & & Novi Sanzhary & 8896 & 32.165 \\
\hline 29 & & Mala Pereshchepyna & 4048 & 238.088 \\
\hline 30 & & Rudenkivka & 3843 & 103.552 \\
\hline 31 & Pyriatyn & Pyriatyn & 16802 & 97.620 \\
\hline 32 & \multirow[t]{5}{*}{ Poltava } & Zavorsklo & 3316 & 114.130 \\
\hline 33 & & Kolomatske & 2279 & 90.201 \\
\hline 34 & & Machukhy & 7959 & 247.083 \\
\hline 35 & & Tereshky & 8742 & 86.873 \\
\hline 36 & & Shcherbani & 13113 & 98.773 \\
\hline 37 & Reshetylivka & Reshetylivka & 11061 & 174.260 \\
\hline 38 & \multirow[t]{2}{*}{ Semenivka } & Obolon & 2528 & 137.366 \\
\hline 39 & & Semenivka & 10777 & 271.998 \\
\hline 40 & \multirow[t]{3}{*}{ Khorol } & Klepachi & 2665 & 126.282 \\
\hline 41 & & Novoavramivka & 2632 & 137.201 \\
\hline 42 & & Pokrovska Bahachka & 2501 & 121.249 \\
\hline 43 & Chornukhy & Chornukhy & 9142 & 512.396 \\
\hline 44 & Chutove & Skorokhodove & 5245 & 135.636 \\
\hline \multirow[t]{2}{*}{45} & Shyshaky & Shyshaky & 14583 & 611.534 \\
\hline & TOTAL & - & 315526 & 8671.400 \\
\hline
\end{tabular}


aries' prosperous creation. Above all, Poltava Region growth poles' ways of developing are favourable transport-geographical location, availability of highly skilled labour resources, the sufficient level of market infrastructure objects' level, business climate agreeable for small business development, and investment attractiveness. The main goal of the reformation process is to consolidate capable UACs with much higher social-economic potential is to intensify their budgetary capacity and functional independence.

The perspective plan of Poltava Region communities' formation envisaged the unification of more than 70 areal entities, providing qualitatively new service level in such spheres as housing and utility services, education, health care, social protection, and culture.

All the UACs' modelling criteria, in fact, have its deep base on the fundamental theses of socialgeographic zoning, justifying the new model on the area historical-geographical forming peculiarities; area natural-geographical integrity and continuity; attraction to the forming nucleus as centre of all the services. They also include complex-proportional development of UAC as a separate areal system based on the previously formed infrastructural interrelations, on the principles of rational nature use, balanced areas development, and perspectives of their growth.

The regionally-concretized vectors or landmarks of development of territories of Poltava Region include: an intense growth of specific branches of economy specialization; restoration of agricultural and transport engineering; production of equipment for food and light industry; expansion of grain, sugar beet and livestock specialized complexes. The landmarks of areal development of the region likewise include widening the region positions on the national and globe food markets, extension of scientific-technical level of metallurgical complex and chemical industry, enlargement of tourism and recreation potential.

In fact, the dynamic growth poles' formation of Poltava Region needs the implementation of diverse by scope and spheres approaches and types of innovations. Rather fast growth of growth poles', mainly in depressive districts of Poltava Region, is possible, first and foremost, due to localities, specializing in traditional branches of manufacturing industry. Such industries have, as a rule, rather formed ways of the development and rather saved integral production infrastructure. Another indicative condition of the further extension of these localities is scientific and innovative modernization of agricultural branches, focused on producing raw materials for the food and light industries. On the one hand, they provide rapid growth in agricultural production volumes and rates as well as solving a number of rural depressive areas' social problems. On the other hand, these branches can settle the problem of supplying the manufacture industry traditional branches with raw materials. As a result of the restoration of traditional economy branches and the competitiveness of their production in regional and national markets, the implementation of modern innovative technologies in production and social infrastructure, the areas are to overcome depressiveness and get regional development stimulated.

The population amount dynamics of the region is marked as another noteworthy indicator, which determines the dynamics of the population life conditions and quality, therefore, the growth of population amount and life quality shows the positive development dynamics of UAC's centre. Only then, there are reasons to believe that such UAC centre transforms into the growth pole. Thorough analysis of UAC centres' population amount dynamics testified the fact the Poltava Region UACs network has gone unbalanced and got in a state of a crisis. An average $60 \%$ of the region population lives at depressive localities.

In Poltava Region, population amount dynamics' indicators largely correlate with indicators of its migration activity. The last ones have been rather labile indicators, clearly capture the dynamics specificity of the area social-economic development, representing job positions' possibilities and population's selfrealization in the localities. The availability and expansion of such opportunities in various localities reveal the acquisition of growth poles by them (Pidhrushnyy, 2013). Almost all of the region towns (except of Poltava, Kremenchuh, and Horishni Plavni) exemplify a negative migration balance, being unfavourable for living and unable to bare the status of area-forming nucleus in modern way of life.

The level of their economic activity is also quite significant indicator of growth poles, which is the correlation between a number of business entities of the centre and corresponding average national indicator. Therefore, Poltava, Kremenchuh, also some small areas around them indicate the highest level of economic activity. The rest of districts of the region outside the regional centres' boundaries hold the status of area with decreased economic activity. One of the specific indicators, highlighting the social-economic growth positive tendencies in certain districts of the region, is the level of FDI volumes, scilicet the amount of foreign investors' equity, invested in business objects, affects the development of socialeconomic activity centres (Pidhrushnyy, 2017). The 
largest FDI volumes are concentrated in Poltava, Horishni Plavni, and Kremenchuh. Areal division of these FDI volumes tends to be extremely uneven in Poltava Region.

Taking into in-depth consideration the criteria and indicators of Poltava Region UACs' centres development, it is fair to note that their groups can be distinguished by the social-economic development poles according to the level of formation in as follows:

1) centres-poles, being under formation;

2) centres, which have some prerequisites to transform into growth poles;

3) centres with insufficient capacity to transform into growth poles.

Up-to-date situation forms a distinct marker the only formed social-economic development poles in Poltava Region are Poltava and Kremenchuh. Such towns as Horishni Plavni, Myrhorod, Lubny, and Hadiach belong to the group of centres, being under formation. Karlivka, Pyriatyn, Lokhvytsa, Zinkiv, Hlobyne, and Kobeliaky have outlined vivid prerequisites to further transformation into growth poles. The remainder, constituted by Velyka Bahachka, Kozelshchyna, Mashivka, Novi Sanzhary, Opishnia, Chornukhy, and Shyshaky, renders a low profile and stands for a group of UACs with insufficient capacity to transform into social-economic growth poles in Poltava Region.

Previously made all-embracing analysis disclosed the fact the majority of Poltava Region regional centres comprises the $2^{\text {nd }}$ and the $3^{\text {rd }}$ groups, been in a state of formation, or has some prerequisites to further transformation into growth poles. Those UACs, constituted by such localities as Bilotserkivka, Butenky, Velyki Sorochyntsi, Drabynivka, Zavorsklo, Zasullia, Klepachi, Kolomatske, Krasna Luka, Lanna, Mala Pereshchepyna, Machukhy, Mykhailivka, Nedoharky, Nekhvoroshcha, Novoavramivka, Novoznamianka, Obolon, Omelnyk, PetrivkaRomenska, Pishchane, Pokrovska Bahachka, Pryshyb, Rokyta, Rudenkivka, Sencha, Serhiivka, Skorokhodove, Tereshky, and Shcherbani, possess low potential ability and low level of formation as growth poles. Actually, they have no appropriate prerequisites and possibilities, even by the previous predication, to transform into growth poles, except of Bilotserkivka and Velyki Sorochyntsi. The spectrum of the mentioned above aspects makes serious challenge and threat to administrative-areal reform implementation on the regional level and acquire system of measures to transform UAC centres into a balanced system of growth poles.

An efficient solution of the regional development issues is closely connected to the growth poles' system formation. It also deeply touches upon the issue of Poltava Region specialization areas of the economic complex. They are these branches that unfold stimulating and at the same time stabilizing effect, broadening development impulses over surrounding territory simultaneously to providing the narrowing of depressive territories. Thus, the base of Poltava Region growth poles' forming lies in the transformation of social-economic activity centres.

Conclusions. The results of the given research open the further possibility to formulate a set of measures, concerning the Poltava Region social-economic activity centres' transformation into the growth poles. They are space clustering on the base of comprehensive application of real terms and resources under mandatory ecosystem balance insurance, environmental quality preservation and restoration, achievement of high life quality and well-being of the population, economy re-industrialization insurance on the new technical and technological basis, innovative economic development implementation, grounded on the smart-specialization, rural areas' monospecialization overcoming. One also can speak about food, light industries and agricultural engineering local economic clusters' creation; high-levelled areas' infrastructure potential achieving; priority support of creative industry, recreation, tourism, logistics, and exhibition activity development; usage of material (natural, historical and cultural monuments, sacred objects) and non-material (area brand, labourresource and innovative-scientific potential) assets, able to make the social-economic increase effects.

Crucial indicators in achieving these goals should provide the population employment growth in non-agricultural activity, the development and implementation of programmes of localities' improvement, and the increase of the comfort of living as well as the level of social-cultural and household services to the inhabitants. Likewise, they are the elaboration and implementation of business plans of areal development, and the creation of innovative clusters and industrial parks for efforts incorporation and competitiveness enhancing.

\section{References}

Malchykova, D. S., 2014. Teoretyko-metodolohichni i metodychni zasady heoplanuvannya sil's'koyi mistsevosti na rehional'nomu rivni [Theoretical, methodological and methodic principals of rural 
geoplanning on the regional level]. Hrin' D.S., Kherson. (in Ukrainian).

Mezentsev, K. V., Pidhrushnyy H. P., Mezentseva N. I., 2014. Rehional'nyy rozvytok v Ukrayini: suspil'no-prostorova nerivnist' i polyaryzatsiya: Monohrafiya [Regional Development in Ukraine: the socio-spatial inequality and polarization]. DP «Print servis», Kyiv. (in Ukrainian).

Pidhrushnyy, H. P., 2013. Znachennya polyusiv sotsial'noekonomichnoho rozvytku u vdoskonalenni terytorial'noyi orhanizatsiyi suspil'stva [The importance of the poles of socio-economic development in improving the territorial organization of society]. Ukrainian Journal of Geography. Issue 4. 40-47. (in Ukrainian).

Pidhrushnyy, H. P., 2017. Formuvannya systemy polyusiv zrostannya v Ukrayini yak peredumova yiyi perekhodu do modeli politsentrychnoho prostorovoho rozvytku [Formation of the growth poles system in Ukraine as a prerequisite for its transition to a model of polycentric spatial development]. Ukrainian Journal of Geography. Issue 1. 48-54. (in Ukrainian).

Pilipenko, I. O., 2015. Suspil'no-geografichna periferija: koncepcija, parametrizacija i delimitacija [Human-geographical periphery: concept, parameterization and delimitation]. Hrin' D.S., Kherson. (in Ukrainian).

Rudenko, L. G., Li`sovskij, S. A., Marunyak, Ye. O., 2016. Vikliki i zagrozi prostorovogo rozvitku Ukrayini na shlyakhu do yevrointegracziyi [Challenges and threats to Ukraine's spatial development on the path to European integration]. Ukrainian Journal of Geography. Issue 1. 41-46. (in Ukrainian).

Shevchuk, S. M., 2019. Model' transformatsiyi administratyvno-terytorial'noyi systemy Poltavs'koyi oblasti [The model of the transformation of administrative-territorial system of Poltava region]. Fundamental And Applied Researches: Contemporary Scientifical and practical Solutions and Approaches. Vol. V . 477-483. (in Ukrainian).

Topchiyev, O. H., Malchykova, D. S., Yavorska, V. V., 2015. Rehionalistyka: heohrafichni osnovy rehionalnoho rozvytku i rehionalnoyi polityky [Regionalistics: geographical bases of regional development and regional policy]. OLDI-PLYuS, Kherson. (in Ukrainian).

Zapotoczkij, S. P., 2012. Regionalna konkurentospromozhnist: suspilno-geografichni zasadi formuvannya [Regional competitiveness: human-geographical principles of formation]. Biznes Media Konsalting, Kyiv. (in Ukrainian). 